\title{
DESCRIPTIVE ANALYSIS OF URGENT MEDICAL INTERVENTIONS BASED ON AIR POLLUTION IN SLAVONSKI BROD, CROATIA
}

\author{
CVITKOVIĆ ANTE ${ }^{1,2}$, IVIĆ-HOFMAN IGOR ${ }^{1}$, BARIŠIN ANDREJA $^{3}$, CAPAK KRUNOSLAV $^{3}$, \\ VIDIĆ SONJA ${ }^{5}$, VAĐIĆ VEDRAN ${ }^{4}$, ĆOSIĆ VESNA ${ }^{2}$, MIŠKIĆ BLAŽENKA ${ }^{2,6}$ \& VALJETIĆ MARIJANA ${ }^{1}$ \\ ${ }^{1}$ Institute of Public Health of Brod-Posavina County, Croatia \\ ${ }^{2}$ Josip Juraj Strossmayer University of Osijek, Croatia \\ ${ }^{3}$ Croatian Institute of Public Health, Croatia \\ ${ }^{4}$ EKONERG - Energy and Environmental Protection Institute, Croatia \\ ${ }^{5}$ Meteorological and Hydrological Service, Croatia \\ ${ }^{6}$ General Hospital Dr. Josip Benčević, Slavonski Brod, Croatia
}

\begin{abstract}
Air pollution is a big public health problem. Short term and long-term exposure to air pollutants have different health effects. The purpose of this research is to determine whether $\mathrm{PM}_{10}, \mathrm{PM}_{2.5}, \mathrm{H}_{2} \mathrm{~S}$ and meteorological parameters have impact on frequency of urgent interventions in ERs (Institute of Emergency Medicine of Brod-Posavina County and Integrated Emergency Hospital Admission) in 2016 in the area of Slavonski Brod. Data were collected from four sources: Institute of Emergency Medicine of Brod-Posavina County, Integrated Emergency Hospital Admission, Meteorological and Hydrological Service data and Croatian Agency for Environment and Nature. During 2016, 56349 interventions in ERs were recorded. Weak but statistically significant positive correlation was established between $\mathrm{PM}_{10}$ (correlation coefficient 0.103 ; $\mathrm{p} 0.043$ ) and $\mathrm{PM}_{2.5}$ (correlation coefficient $0.106 ; \mathrm{p} 0.043$ ) with the number of interventions in ERs. The correlation of mean relative humidity was statistically significant but negative (correlation coefficient $-0.109 ; \mathrm{p} 0.038$ ). Connection between minimum and maximum temperature, $\mathrm{H}_{2} \mathrm{~S}$ and mean pressure values was not established. These results point to the importance of reducing air pollution with $\mathrm{PM}_{10}$ and $\mathrm{PM}_{2.5}$ in Slavonski Brod.
\end{abstract}

Keywords: particulate matter, $P M_{2.5}, P M_{10}$, pollutants, hydrogen sulphide.

\section{INTRODUCTION}

A great risk for global health, recognized by governments, institutions and citizens, is air pollution [1]. It is estimated that 6 million of premature deaths in 2012 is caused by polluted air [1]. The reasons for premature deaths are mostly ischaemic heart disease and strokes then chronic obstructive pulmonary disease or acute lower respiratory infections and lung cancer [2]. Air pollutants have short term and long-term influence on human health.

People can be exposed to $\mathrm{PM}_{10}$ and $\mathrm{PM}_{2.5}$ for hours and days and for months and years. Both exposures include: respiratory and cardiovascular morbidity, such as aggravation of asthma, respiratory symptoms and an increase in hospital admissions; mortality from cardiovascular and respiratory diseases and from lung cancer [3], [4]. Particulate matter influence on spontaneous miscarriages, autism diseases, attention disorders, dementia and brain tumours has also been studied [5]-[8]. Short-term exposure to $\mathrm{PM}_{10}$ has big influence on respiratory health, for mortality, and long-term exposure even bigger [4]. Daily mortality caused by all reasons increases by $0.2-0.6 \%$ per $10 \mu \mathrm{g} / \mathrm{m}^{3}$ of $\mathrm{PM}_{10}$ [4]. $\mathrm{PM}_{2.5}$ is even a riskier element than $\mathrm{PM}_{10}$ [4]. Increased concentrations of $\mathrm{PM}_{2.5}$ were associated with increased risks at lag days $0-1$ of all-cause mortality $\left(0.26 \%\right.$ increase per $\left.10 \mu \mathrm{g} / \mathrm{m}^{3}\right)$, nonaccidental deaths $(0.25 \%)$, circulatory deaths $(0.39 \%)$, respiratory deaths $(0.43 \%)$, intentional self-harm deaths $(1.94 \%)$ and nervous system deaths $(0.9 \%)$, although the observed increase was not statistically significant for the final one rarer cause of death [9]. 
Especially vulnerable groups are people with pre-existing lung or heart disease, children and older people [4]. A safe level of exposure or a threshold below which adverse health effects do not occur does not exist as a proof [4]. There is evidence of connection between the concentrations of particulate matters $\left(\mathrm{PM}_{2.5}, \mathrm{PM}_{2.5-10}, \mathrm{PM}_{10}\right)$ and their chemical components (soluble ions) with hospital admissions because of circulatory and respiratory diseases among older people in a medium-sized city in Brazil [10]. $\mathrm{PM}_{2.5}$ showed a remarkable connection with circulatory system diseases, and the risk of hospitalization increased by $19.6 \%$ per $10 \mu \mathrm{g} / \mathrm{m}^{3}$ [1]. Exposures to $\mathrm{PM}_{10}, \mathrm{PM}_{2.5}$, and $\mathrm{NO}_{2}$ showed a significant association with emergency admissions for ischemic heart disease and heart rhythm disturbances [11]. The estimated risk reduction for ischemic heart disease admissions was $2.44 \%, 2.34 \%$, and $3.93 \%$ for a $10 \%$ reduction in $\mathrm{PM}_{10}, \mathrm{PM}_{2.5}$, and $\mathrm{NO}_{2}$ respectively [11].

Smell of hydrogen sulphide is very annoying [1]. The average value of the threshold odour according to WHO is $11 \mathrm{mg} / \mathrm{m}^{3}$ [12]. There are no completely finished investigations on long-term exposure to low concentrations of hydrogen sulphide. There is a research among the workers in the water and wastewater network that showed an increased number of patients with obstructive lung disease in workers in the wastewater network, exposed to higher concentrations of hydrogen sulphide, than in workers employed in water network [13].

Annual reports on air quality in Slavonski Brod, Croatia, show that the atmosphere is polluted with respect to: $\mathrm{H}_{2} \mathrm{~S}, \mathrm{PM}_{10}$ and $\mathrm{PM}_{2.5}$ in 2015 [1]. A similar situation was in previous years [15]. Air pollution is in the centre of attention of citizens of Slavonski Brod since the oil refinery in neighbouring country of Bosnia and Herzegovina was put into operation in 2008. Researches on the impact of pollutants on human health in the area of Slavonski Brod are rare. Given the impact on health, the aim of this paper is to show the influence of particulate matters, hydrogen sulphide and meteorological conditions on the frequency of emergency medical interventions.

\section{METHODS}

The analysis in the town of Slavonski Brod for the period of time from January 1-December 12, 2016. was carried out using data from four sources:

1. System eHitna - interventions of urgent medical help of the Institute of Emergency Medicine of Brod-Posavina County (Croatian acronym ŽZHM), the branch office in Slavonski Brod. Data include field interventions of urgent medical help stuff in Slavonski Brod and ER visits.

2. OHBP data - visits to Integrated Emergency Hospital Admission (Croatian acronym: OHBP).

3. Meteorological and Hydrological Service data (Croatian acronym DHMZ) temperature minimum and temperature maximum, mean value of air pressure and mean value of relative humidity per day.

4. Croatian Agency for Environment and Nature (Croatian acronym HAOP) data -air quality for $\mathrm{PM}_{2.5}$ and $\mathrm{PM}_{10}$ per day based on gravimetry and for $\mathrm{H}_{2} \mathrm{~S}$ per day, data from two automatic measuring stations (SL1 and SL2).

Data from ŽZHM and from OHBP were compiled and observed in order to comprehend the sum of interventions/visits per day (all interventions/visits per day without deleting duplicate records). There were no data about patients place of residence neither patients were filtered by their country of residence. Total number of all interventions/visits per day over one year was investigated. All diseases were included in the analysis. Meteorological and air 
quality data were added to each day. Values of $\mathrm{PM}_{2.5}, \mathrm{PM}_{10}$ and $\mathrm{H}_{2} \mathrm{~S}$ were also analysed regarding the limit values $\left(25 \mu \mathrm{g} / \mathrm{m}^{3}\right.$ for $\mathrm{PM}_{2.5}, 50 \mu \mathrm{g} / \mathrm{m}^{3}$ for $\mathrm{PM}_{10}$ and $5 \mu \mathrm{g} / \mathrm{m}^{3}$ for $\left.\mathrm{H}_{2} \mathrm{~S}\right)$. There was missing meteorological and air quality data from automatic measuring stations. Missing cases for correlations between number of interventions/visits and environmental variables were excluded pairwise.

Numeric variables were described by the central values and the dispersion measure, conditioned by data distribution. Shapiro-Wilks / Kolmogorov-Smirnov's assay was used to test continuous variables for normal distribution. Pearson correlation coefficient was used for testing of direction and strength of the correlation between the variables for the variables distributed normally and Spearman correlation coefficient was used in a case when the variables were not distributed normally. Mann-Whitney test was used to determine the difference of continuous variables between the two groups. In data analysis, MS Excel and SPSS 23 programme package were applied. To conduct the research, Ethics Committee of the Croatian Institute of Public Health gave the approval no. 80-436 /1-16.

\section{RESULTS}

In the observed period, there were 41674 interventions in OHBP and 14675 interventions in ŽZHM. The total number of interventions in both OHBP and ŽZHM was 56349.

Measures of central tendency and variance of variables are shown in Table 1.

Table 1: Measures of central tendency and variance of variables are shown.

\begin{tabular}{|l|c|c|c|c|c|c|}
\hline Variable & $\mathbf{N}$ & Mean & Median & SD & Min & Max \\
\hline $\begin{array}{l}\text { Total number of } \\
\text { interventions }\end{array}$ & 366 & 153.96 & 152 & 25.84 & 101 & \\
\hline $\begin{array}{l}\text { Number of } \\
\text { interventions -ŽZHM }\end{array}$ & 366 & 40.10 & 36 & 16.05 & 15 & 107 \\
\hline $\begin{array}{l}\text { Number of } \\
\text { interventions - OHBP }\end{array}$ & 366 & 113.86 & 113 & 15.70 & 75 & 200 \\
\hline $\begin{array}{l}\text { Minimum } \\
\text { temperature }\left({ }^{\circ} \mathrm{C}\right)\end{array}$ & 365 & 5.94 & 6.2 & 7.35 & -10.8 & 21.4 \\
\hline $\begin{array}{l}\text { Maximum } \\
\text { temperature }\left({ }^{\circ} \mathrm{C}\right)\end{array}$ & 365 & 18.11 & 17.7 & 9.51 & -7 & 36.5 \\
\hline $\begin{array}{l}\text { Medium air pressure } \\
(\mathrm{hPa})\end{array}$ & 365 & 1006.97 & 1006.12 & 8.05 & 985.91 & 1029.68 \\
\hline $\begin{array}{l}\text { Relative humidity } \\
(\%)\end{array}$ & 365 & 77.11 & 76.81 & 10.44 & 46.35 & 98.08 \\
\hline SL1_PM $2.5\left(\mu \mathrm{g} / \mathrm{m}^{3}\right)$ & 366 & 41.36 & 23.36 & 49.61 & 1.75 & 518.77 \\
\hline SL2_PM ${ }_{2.5}\left(\mu \mathrm{g} / \mathrm{m}^{3}\right)$ & 352 & 34.73 & 21.08 & 35.94 & 2.13 & 262.55 \\
\hline SL1_PM $10\left(\mu \mathrm{g} / \mathrm{m}^{3}\right)$ & 366 & 49.59 & 30.51 & 52.68 & 3.25 & 537.26 \\
\hline SL2_PM ${ }_{10}\left(\mu \mathrm{g} / \mathrm{m}^{3}\right)$ & 350 & 40.86 & 28.49 & 35.75 & 0.43 & 266.42 \\
\hline SL1_H ${ }_{2} \mathrm{~S}\left(\mu \mathrm{g} / \mathrm{m}^{3}\right)$ & 350 & 1.65 & 1.37 & 1.32 & 0.15 & 11.97 \\
\hline SL2_H ${ }_{2} \mathrm{~S}\left(\mu \mathrm{g} / \mathrm{m}^{3}\right)$ & 330 & 2.66 & 2.63 & 1.20 & 0.95 & 15.72 \\
\hline
\end{tabular}


Values on the SL1 station for $\mathrm{PM}_{2.5}$ were within limit values during 197 days (53.83\%), during 259 days (70.77\%) for $\mathrm{PM}_{10}$ and during 342 days $(93.44 \%)$ for $\mathrm{H}_{2} \mathrm{~S}$ while on the SL2 station, values were within recommended values during 200 days (54.64\%) for $\mathrm{PM}_{2.5}$, during 266 days (72.68\%) for $\mathrm{PM}_{10}$ and during 325 days $\left(88.8 \%\right.$ ) for $\mathrm{H}_{2} \mathrm{~S}$. Values for $\mathrm{H}_{2} \mathrm{~S}$ on $\mathrm{SL} 1$ were not recorded for 16 days and values for $\mathrm{PM}_{10}$ and $\mathrm{PM}_{2.5}$ were recorded for every single day. $3.83 \%$ of values for $\mathrm{PM}_{2.5}$ on the SL2 station were not recorded, $4.37 \%$ were not recorded for $\mathrm{PM}_{10}$ as well as $9.84 \%$ for $\mathrm{H}_{2} \mathrm{~S}$.

Distribution normality test (Shapiro-Wilks/Kolmogorov-Smirnov test) showed that none of the observed continuous variables were normally distributed.

Correlations between number of interventions/visits and environmental variables (meteorological data and data on $\mathrm{PM}_{2.5}, \mathrm{PM}_{10}$ and $\mathrm{H}_{2} \mathrm{~S}$ ) as well as the significance of correlation with a level significance of $5 \%(\mathrm{p}<0)$ are shown in Table 2. On the SL1 station, there was a significant weak correlation $(\mathrm{RS}=0.103, \mathrm{p}=0.049)$ between $\mathrm{PM}_{2.5}$ and the number of interventions per day and weak correlation $(\mathrm{RS}=0.106, \mathrm{p}=0.043)$ between $\mathrm{PM}_{10}$ and the number of interventions per day. On the SL2 station, there was a significant weak correlation $(\mathrm{RS}=0.120, \mathrm{p}=0.025)$ between $\mathrm{PM}_{10}$ and the number of interventions. Negative statistically significant correlation with relative humidity $(\mathrm{RS}=-0.109, \mathrm{p}=0.038)$ was recorded.

\section{DISCUSSION}

The results of air quality measurement in Slavonski Brod do not show any improvement over previous periods. The $\mathrm{PM}_{10}, \mathrm{PM}_{2.5}$ and $\mathrm{H}_{2} \mathrm{~S}$ values reached high concentrations (maximum $537.26 \mu \mathrm{g} / \mathrm{m}^{3}, 518.77 \mu \mathrm{g} / \mathrm{m}^{3}, 15.72 \mu \mathrm{g} / \mathrm{m}^{3}$ ). The Croatian air quality law assesses air quality as the first (clean) or second category (polluted). Regarding particulate matter and $\mathrm{H}_{2} \mathrm{~S}$, air in Slavonski Brod is in the second category (polluted). In addition to poor air quality data suggest that concentrations for $\mathrm{PM}_{2.5}$ within the recommended values were 197 of 366 days, and for $\mathrm{PM}_{10} 259$ days.

Results of this study for 2016, show positive, statistically significant, but weak correlation between $\mathrm{PM}_{2.5}$ and $\mathrm{PM}_{10}$ concentrations and daily number of emergency interventions

Table 2: Correlations between number of interventions/visits and environmental variables (meteorological data and data on $\mathrm{PM}_{2.5}, \mathrm{PM}_{10}$ and $\mathrm{H}_{2} \mathrm{~S}$ ).

\begin{tabular}{|l|cc|}
\hline & \multicolumn{2}{|c|}{$\begin{array}{c}\text { Number of interventions per day } \\
\text { Correlation coefficient }\end{array}$} \\
\hline Medium relative humidity & -0.109 & $\mathbf{0 . 0 3 8}$ \\
Minimum temperature & -0.038 & 0.472 \\
Maximum temperature & 0.028 & 0.598 \\
Medium air pressure & 0.019 & 0.721 \\
SL1 $\mathrm{PM}_{2.5}$ & 0.103 & $\mathbf{0 . 0 4 9}$ \\
SL2 $\mathrm{PM}_{2.5}$ & 0.098 & 0.066 \\
SL1 $\mathrm{PM}_{10}$ & 0.106 & $\mathbf{0 . 0 4 3}$ \\
SL2 $\mathrm{PM}_{10}$ & 0.120 & $\mathbf{0 . 0 2 5}$ \\
SL1 $\mathrm{H}_{2} \mathrm{~S}$ & 0.077 & 0.151 \\
SL2 $\mathrm{H}_{2} \mathrm{~S}$ & 0.054 & 0.328 \\
\hline
\end{tabular}


registered with ŽZHM and OHBP. Number of interventions increased with the increase of concentration levels. Similar results have been obtained in some other research studies [16], [17]. Results for $\mathrm{PM}_{2.5}$ and $\mathrm{PM}_{10}$ for the first 8 months of 2016 are also similar [18]. The difference is related to $\mathrm{H}_{2} \mathrm{~S}$ which has not been statistically linked with emergency interventions during 2016 while for the first 8 months the correlation of $\mathrm{H}_{2} \mathrm{~S}$ with the number of emergency interventions was inconsistent [18]. The connection of meteorological parameters and air pollution with emergency interventions due to cardiovascular disease was established in Zagreb [19]. The authors found a statistically significant correlation between the number of aggravated chronic obstructive pulmonary disease in adults and the total suspended particles concentrations on the previous day [20]. Among other results, the occurrence of respiratory diseases showed positive Spearman's correlation with the values of air humidity, $\mathrm{PM}_{10}$ and negative correlation with the values of air temperature and pressure. The occurrence of respiratory diseases showed correlation with weather conditions and air pollutants despite the legally permitted values in the region with a humid continental climate [21] Spearman's correlation yielded positive correlation between the occurrence of arrhythmias and air humidity on the day $(\mathrm{r}=0.07)$, and $1(\mathrm{r}=0.08,2(\mathrm{r}=0.09)$ and 3 days before $(\mathrm{r}=0.09)$, palpitations and air humidity on the day $(\mathrm{r}=0.11)$, and $1(\mathrm{r}=0.09), 2(\mathrm{r}=0.07)$ and 3 days before $(\mathrm{r}=0.10)$, and $\mathrm{PM}_{10}(\mathrm{r}=0.11)$ particles on the day of emergency department (ED) admission; and atrium fibrillation/undulation and air humidity 2 days before $(r=0.08)$ ED admission $(p<0.05$ all)[22]. There was a very weak positive correlation of the occurrence of cardiac arrhythmias with air humidity and concentration of air pollutants in the region with a humid continental climate [22]. Our research has shown a negative correlation between mean relative humidity and number of interventions. A $10 \mu \mathrm{g} / \mathrm{m}^{3}$ decrease in concentration would imply 256 less hospital admissions and savings of approximately R $\$ 220,000$ in a medium-sized city [23]. Other studies also show the connection between particulate matter and hospital admissions due to stroke as well as between children pneumonia and air pollution [24], [25]. Certain pollution is associated with elevated hospital admissions due to respiratory diseases and ischemic stroke [26], [27].

The highest number of admissions (37.2\%) occurred during winter, followed by autumn (24.1\%), spring (23.9\%), and summer (14.7\%) [17]. Maximum, minimum, and mean temperatures were associated similarly with the number of hospitalization [28].

In our research, we did not find the connection of emergency medical interventions with minimal and maximum temperature. A significant negative correlation was found between cardiovascular diseases-related emergency visits and air temperature measured no more than three days prior to the visit, and the highest negative correlation coefficient was measured two days earlier [19].

The results for the first 8 months showed a weak negative correlation between minimum/maximum temperature and the daily number of patients reporting to the emergency clinic, specifically in the winter months at low temperature and low wind events, can be partially explained with increased heating on wood and charcoal a common way of heating by the local population [18].

In Croatia, the emergency health service is organized through a system of emergency clinic and the Integrated Emergency Hospital Admission. Although we did not specifically analyse the specific reason why patients visit emergency service, connections with high concentrations of $\mathrm{PM}_{10}$ and $\mathrm{PM}_{2.5}$ were established. These results provide basis for further recommendations and on the continuation of investigation that would lead to an adequate advisory system for general public in cases of pollutant concentrations exceeding prescribed threshold or guideline limit values. 
Some countries have introduced recommendations such as the Air Quality Index [29]. Specific health advice/warning information (for example Daily Air Quality Index) for the general public and sensitive individuals (those with pre-existing illness and the elderly) is developed already for example in United Kingdom [29]. It is based on the level of the Daily Air Quality Index and are disseminated via Internet [29]. Croatian Agency for Environment and Nature publishes the index without description of health impacts [30]. Parameters that are monitored include gases ( $\mathrm{NO}, \mathrm{NO}_{2}, \mathrm{CO}, \mathrm{O}_{3}, \mathrm{H}_{2} \mathrm{~S}, \mathrm{SO}_{2}$, benzene, $\left.\mathrm{NH}_{3}\right)$, particulate matter $\left(\mathrm{PM}_{10}\right.$ and $\left.\mathrm{PM}_{2.5}\right)$, and meteorological data (wind speed and direction, temperature and pressure) [30]. If the parameter values exceed the corresponding regulation limits for three consecutive hours, the web service generates an alert for population groups at risk [30]. Incorporating health tips to vulnerable groups with the use of new technologies that make it available at any time, for example cell phones, will be a new step in protecting the health of people [18]. Such information should serve as a recommendation on how to act and avoid unnecessary exposure [18].

Considering constraints (lack of data on residence) and specifics of the sample (the domain of emergency medicine and the logging of visits), test strength and generalisation of conclusions on for the entire population of Slavonski Brod can be limited.

It is necessary to continue with further research, to jointly interpret the results of complementary surveys and to analyse further additional parameters and indicators of current pollution.

\section{CONCLUSION}

Statistically significant positive correlation between $\mathrm{PM}_{10}$ (correlation coefficient $0.103 ; \mathrm{p}$ 0.043 ) and $\mathrm{PM}_{2.5}$ (correlation coefficient 0.106 ; $\mathrm{p} 0.043$ ) with the number of medical interventions in emergency rooms was established, though weak. The correlation of mean relative humidity was statistically significant but negative (correlation coefficient $-0.109 ; \mathrm{p}$ 0.038). These findings point to the need for further researches on this big public health issue. Also, these results point to the importance of reducing air pollution with $\mathrm{PM}_{10}$ and $\mathrm{PM}_{2.5}$ in Slavonski Brod.

\section{ACKNOWLEDGEMENTS}

I would like to express my deep gratitude to Mr Marko Brkić from The Croatian Institute of Public Health who did the statistics. Results shown in this study are a part of Study of impact of environmental factors on human health which is financed by Ministry of Health of the Republic of Croatia.

\section{REFERENCES}

[1] Evolution of WHO air quality guidelines: past, present and future. Copenhagen, WHO Regional Office for Europe, Online. www.euro.who.int/data/assets/pdf_file/0019/ 331660/Evolution-air-quality.pdf?ua=1. Accessed on: 20 Oct. 2017.

[2] World Health Organisation (WHO), Online. www.who.int/mediacentre/factsheets/ fs313/en/. Accessed on: 16 Oct. 2017.

[3] Zhou, Y., Li, L. \& Hu, L., Correlation analysis of $\mathrm{PM}_{10}$ and the incidence of lung cancer in Nanchang, China. Int. J Environ Res Public Health, 14(10), 2017. DOI: 10.3390/ijerph14101253.

[4] Health effects of particulate matter, Policy implications for countries in Eastern Europe, Caucasus and central Asia, WHO Regional Office for Europe: Copenhagen, 2013, Online. http://www.euro.who.int/_data/assets/pdf_file/0006/189051/Healtheffects-of-particulate-matter-final-Eng.pdf?ua=1. Accessed on: 10 Oct.2017. 
[5] Fordyce, T.A., Leonhard, M.J. \& Chang, E.T., A critical review of developmental exposure to particulate matter, autism spectrum disorder, and attention deficit hyperactivity disorder. J Environ Sci. Health A Tox Hazard Subst. Environ Eng., pp. 1-31, 2017. DOI: 10.1080/10934529.2017.1383121.

[6] Ha, S. et al., Ambient air pollution and the risk of pregnancy loss: a prospective cohort study. FertilSteril, S0015-0282(17), pp. 31973-31978, 2017. DOI: 10.1016/j. fertnstert.2017.09.037.

[7] Chen, H. et al., Exposure to ambient air pollution and the incidence of dementia: A population-based cohort study. Environ. Int., 108, pp. 271-277, 2017. DOI: 10.1016/j.envint.2017.08.020.

[8] Andersen, Z.J. et al., Long-term exposure to ambient air pollution and incidence of brain tumour: the European study of cohorts for air pollution effects [ESCAPE]. Neuro Oncol., 2017. DOI: 10.1093/neuonc/nox163.

[9] Li, T., Yan, M., Sun, Q. \& Anderson, G.B., Mortality risks from a spectrum of causes associated with wide-ranging exposure to fine particulate matter: A case-crossover study in Beijing, China. Environ Int., 111, pp. 52-59, 2017.

[10] Ferreira, T.M., Forti, M.C., de Freitas, C.U., Nascimento, F.P., Junger, W.L. \& Gouveia, N., Effects of particulate matter and its chemical constituents on elderly hospital admissions due to circulatory and respiratory diseases. Int. J. Environ. Res. Public Health, 13(10), p. 947, 2016.

[11] Devos, S., Cox, B., Dhondt, S., Nawrot, T. \& Putman, K., Cost saving potential in cardiovascular hospital costs due to reduction in air pollution. Sci. Total Environ., 527528, pp. 413-419, 2015. DOI: 10.1016/j.scitotenv.2015.04.104.

[12] Hydrogen sulphide: Human health aspects [Concise International Chemical Assessment Document 53], WHO: Geneva, Online. http://www.who.int/ipcs/ publications/cicad/en/cicad53.pdf. Accessed on: 25 Feb. 2017.

[13] Partti-Pellinen, K., Marttila, O., Vilkka, V., Jaakkola, J.J., Jäppinen, P. \& Haahtela, T., Effects of low level exposure to malodorous sulfur compounds on symptoms. Archives of Environmental Health: An International Journal, 51(4), pp. 315-320, 1996.

[14] Godišnjeizvješće za praćenjekvalitetezrakanapodručjuRepublikeHrvatske za 2015. godinu, Zagreb: Hrvatska agencija za okoliš i prirodu, Online. http://iszz.azo.hr/iskzl/ datoteka?id=31863. Accessed on: 10 Feb. 2017.

[15] Godišnjaizvješća o praćenjukvalitetezrakanapodručjuRepublikeHrvatske, Zagreb: Agencija za zaštituokoliša, Online. http://iszz.azo.hr/iskzl/godizvrpt.htm?pid=0\&t=0. Accessed on: 10 Feb. 2017.

[16] Liu, P., Wang, X., Fan, J., Xiao, W. \& Wang, Y., Effects of air pollution on hospital emergency room visits for respiratory diseases: urban-suburban differences in Eastern China. Int. J. Environ. Res. Public Health, 13(3), p. 341, 2016. DOI: 10.3390/ ijerph13030341.

[17] Zheng, X.Y. et al., Association between air pollutants and asthma emergency room visits and hospital admissions in time series studies: a systematic review and metaanalysis. PLoS One, 18(10), eCollection, 2015. DOI: 10.1371/journal.pone.0138146.

[18] Cvitković, A. et al., Air quality and the number of urgent interventions. Int. J Environ Impacts, 1(2), pp. 162-171, 2018.

[19] Pintarić, S., Zeljkovic, I., Pehnec, G., Nesek, V., Vrsalović, M. \& Pintarić, H., Impact of meteorological parameters and air pollution on emergency department visits for cardiovascular diseases in the city of Zagreb, Croatia. ArhHig Rada Toksikol, 67(3), pp. 240-246, 2016. DOI: 10.1515/aiht-2016-67-2770. 
[20] Pavlović, M., Simić, D. \& Hrsak, J., Emergency cases of chronic obstructive pulmonary disease [COPD] in adults and air pollution in Zagreb. ArhHig Rada Toksikol, 48(4), pp. 365-371, 1997.

[21] Trnjar, K. et al., Correlation between occurrence and deterioration of respiratory diseases and air pollution within the legally permissible limits. Acta Clinica Croatica, 56(2), pp. 210-217, 2017. DOI: doi.org/10.20471/acc.2017.56.02.03,210-217.

[22] Knezović, M. et al., Correlation between concentration of fair pollutants and occurrence of cardiac arrhythmias in a region with humid continental climate. Acta. Clin. Croat., 56(1), pp. 3-9, 2017.

[23] Patto, N.V., Nascimento, L.F., Mantovani, K.C., Vieira, L.C. \& Moreira, D.S., Exposure to fine particulate matter and hospital admissions due to pneumonia: Effects on the number of hospital admissions and its costs. Rev. Assoc. Med. Bras. 1992, 62(4) pp. 342-346, 2016. DOI: 10.1590/1806-9282.62.04.34.

[24] Huang, F. et al., Particulate matter and hospital admissions for stroke in Beijing, China: modification effects by ambient temperature. J. Am. Heart Assoc., 5(7), 2016. DOI: 10.1161/JAHA.116.003437.

[25] Souza, L.S. \& Nascimento, L.F., Air pollutants and hospital admission due to pneumonia in children: a time series analysis. Rev Assoc Med Bras. 1992, 62(2), pp. 151-156, 2016. DOI: 10.1590/1806-9282.62.02.151.

[26] Phung, D. et al., Air pollution and risk of respiratory and cardiovascular hospitalizations in the most populous city in Vietnam. Int J Environ Res Public Health, 13(3), 2016. DOI: 10.3390/ijerph13030341.

[27] Alimohammadi, H., Fakhri, S., Derakhshanfar, H., Hosseini-Zijoud, S.M., Safari, S. \& Hatamabadi, H.R., The effects of air pollution on ischemic stroke admission rate. Chonnam Med J, 52(1), pp. 53-58, 2016. DOI: 10.4068/cmj.

[28] Almagro, P., Hernandez, C., Martinez-Cambor, P., Tresserras, R. \& Escarrabill, J., Seasonality, ambient temperatures and hospitalizations for acute exacerbation of COPD: a population-based study in a metropolitan area. Environ. Res., 140, pp. 554561, 2015. DOI: 10.1016/j.envres.2015.05.005.

[29] UK_Defra., The Daily Air Quality Index. UK Department for Environment, Food and Rural Affairs, London, UK, Online. http://uk-air.defra.gov.uk/air-pollution/daqi. Accessed on: 20 Feb. 2017.

[30] Davila, S., Ilić, J.P. \& Bešlić, I., Real-time dissemination of air quality information using data streams and Web technologies: linking air quality to health risks in urban areas. ArhHig Rada Toksikol, 66(2), pp. 171-180, 2015. DOI: 10.1515/aiht-2015-662633.

[31] Brebbia, C.A., Telles, J.C.F. \& Wrobel, L.C. (eds), Boundary Element Techniques, Springer-Verlag: Berlin and New York, pp. 11-13, 1984.

[32] Osifchin, N. \& Vau, G., Power considerations for the modernization of telecommunications. Proceedings of the Fourth Annual Portable Design Conference, pp. 137-142, 1997.

[33] Test Methods for Evaluating Solid Wastes, Physical/Chemical Methods; U.S. Environmental Protection Agency, Office of Solid Wastes, SW-846, Online. www.epa.gov/epaoswer/hazwastes/test/main.htm. Accessed on: 23 Jun. 2015.

[34] Bratanow, T. \& De Grande, G., Numerical analysis of normal stress in non-Newtonian boundary layer flow. Engineering Analysis, 6(2), pp. 20-25, 1985. 